\title{
The Implementation of Least Square Method on the Palm Shells Sales Forecasting Application
}

\author{
Fahirah \\ Information System, Faculty of Computer Science and \\ Information Technology, Gunadarma University, Depok 16424, Indonesia \\ Email: eva190198@gmail.com \\ Lily Wulandari \\ Information System, Faculty of Computer Science and \\ Information Technology, Gunadarma University, Depok 16424, Indonesia \\ Email: lilypalupi@gmail.com
}

Received: 19 October 2019; Accepted: 08 May 2020; Published: 08 October 2020

\begin{abstract}
Determination of sales targets made by palm shell export companies is often not appropriate and effect the amount of inventory of palm shells sold based on weight which will be reduced if stored too long. Implementation of Least Square method for forecasting the sale of palm shells on web platforms aims to help the company to determine sales targets more accurately. By using this application, companies can forecast for the sale of palm shells for the next month in one year starting from one month after the actual sales period that has been entered. Data testing using Mean Absolute Error (MAPE) shows the error generated is 5.935\%, Black Box testing results reach 100\%, and User Acceptance Testing shows users agree the application in accordance with the requirements and forecasting results is clearly displayed.
\end{abstract}

Index Terms: Sales targets, Palm Shells, Forecasting, Least Square, Application.

\section{Introduction}

Most organizations have large data but only have access to a small portion of the data and do not get much value from what they have [1]. Data can be a valuable resource for businesses and organizations if data mining is done. Data mining is the process of finding interesting patterns or added value in large amounts of data that can be used to help explain current behavior or predict the future for business and organizational purposes [2]. Business people do data mining in order to be able to explore data independently, make informative discoveries, and enter that information to work in their daily business, such as forecasting [1].

Forecasting is an analysis of data mining to predict future values by using the history of previous values [2]. The strategies are used to design models to predict future results of current behavior [2]. There are various kinds of methods that can be used for forecasting, including the time series method using time series data that contains values that are usually generated by continuous measurements from time to time [2].

For example, monthly sales data that are recorded by a company that engaged in the export of palm shells where located in South Jakarta and has palm shell supply sites in Sumatra and Kalimantan. The company determines monthly sales targets as work plans or targets to be achieved in the future. Determination of sales targets means the company strives to forecast future sales by paying attention to future conditions and past conditions [3], but it is often not in accordance with the target because it is done only based on management intuition, not objectively. This will affect the amount of inventory of the company's palm shells.

The companies must conduct sales management as a process that keeps demand and inventory in balance [4]. The amount of inventory that is too little or too much will cause losses to the company. When the client's demand is high and the inventory is too little, the company will find it difficult to fulfill the request so the company will lose the client. If the inventory is too much, the company will suffer losses due to a decrease in the sale value of inventory because the sale of palm shells is based on weight, usually sold per ton and if the palm shell is stored too long it will dry out and reduce its weight.

Based on these problems, an application is needed to help management in determining the sales target of palm shells. This application is useful for determining sales targets that are more objective and more accurate, by using calculations from existing sales data. This affects the determination of the right amount of company inventory to minimize company losses. If the amount of inventory is too much, the company will suffer losses due to the weight of 
the palm shell that is stored too long will be reduced, and if there is too little inventory, the company will suffer losses due to being unable to meet consumer demand. By using this application, company management will more quickly know the estimated number of sales that will have an impact on decision making to determine the amount of inventory needed.

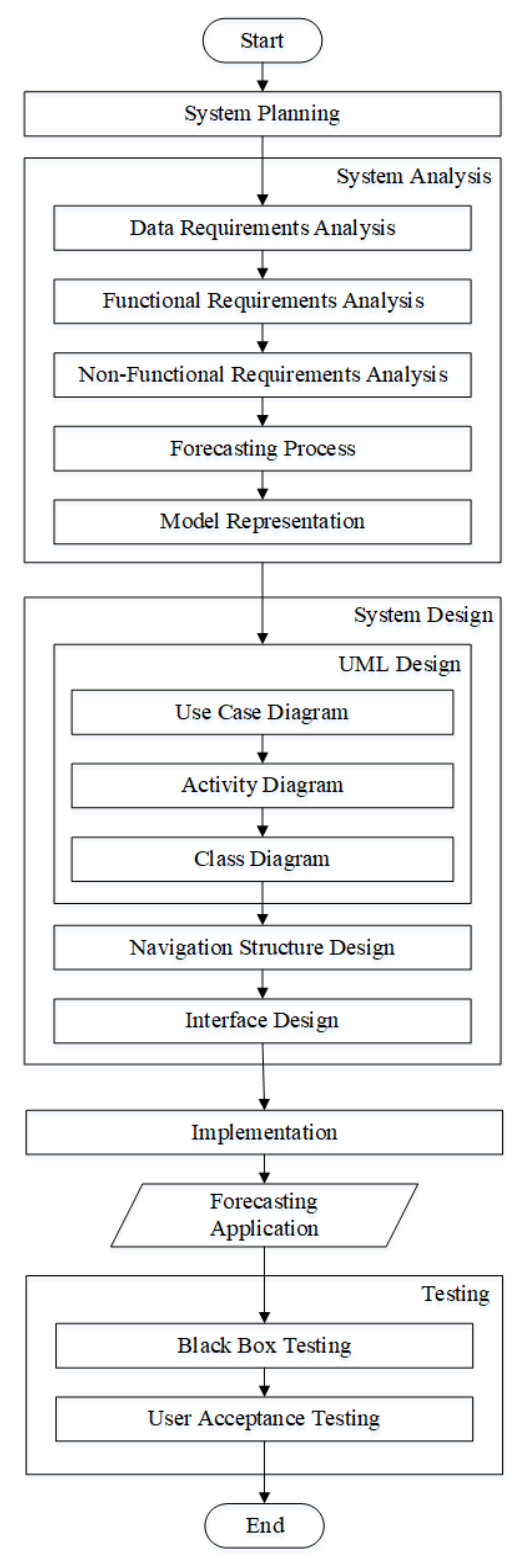

Fig. 1. Scheme of the Research Method

This study aims to implement the Least Square method for sales forecasting on application with web platform. This method is a time series forecasting model by paying attention to data compiled based on the time sequence of sales in the past [3].

Related research has been carried out by other researchers using the Single Moving Average method in making applications to predict motorcycle sales. The results of the comparison between actual sales data with forecasting result generated by the application show that the appropriate data is $24 \%$ and in appropriate data is $76 \%$ so the Single Moving Average method is not suitable for predicting sales [5]. Another research is making a prediction system for selling tofu pong using the Least Square method with the conclusion that the system can predict sales in the next period with a correlation value of 0.88 [6]. Based on the results of the two studies, the Least Square method is more accurate for sales forecasting applications. The system created is desktop based and the data used is daily sales data for two months and the forecasting results are the sales predictions for the next day. 


\section{Methods}

The research method used in this study consisted of the following steps:

1. Collecting data. Data collection techniques used in this study were interviews and document studies. Interviews with Warehouse Managers were conducted to obtain data about the functional requirements of the application. Meanwhile, a document study in the company's sales journal is carried out to obtain the company's monthly sales data that is used in application calculations.

2. Determine forecasting methods. The forecasting method used is the Least Square Method which is one method in the form of periodic data series, and it requires sales data in the past to forecast sales in the future so that results can be determined. [7]. Based on several related studies that have been done previously by other researchers (which have been mentioned in the introduction), this least square method has the smaller correlation value so that this method is considered more accurate.

3. Evaluate forecasting results. After collecting data and determining the forecasting method used, the data is evaluated to find out how much the forecasting error is compared to the real value. This evaluation is done by representing the model and calculating the percentage of errors using Mean Absolute Percentage Error (MAPE). The MAPE results obtained are 5,935\% where MAPE <10\% means this method has a very good forecasting ability.

4. After evaluating the forecasting results and the MAPE results are small, then the forecasting application is made based on the forecasting method.

The steps used in developing these sales forecasting application is Software Development Life Cycle (SDLC). The stages consist of: system planning, system analysis, system design, implementation, and testing. The scheme of the stages can be seen in figure 1 .

\section{A. System Planning}

System development is carried out with the aim of implementing the Least Square method on web-based application for palm shells sales forecasting in a company. This application is expected to help company management in determining more accurate sales targets based on calculations from past data.

\section{B. System Analysis}

System analysis carried out consisted of needs analysis, forecasting process analysis, application process business analysis, and model representation. Needs analysis conducted consists of analysis of data requirements, functional requirements, and non-functional requirements so that the objectives in making the application can be achieved. Analysis of the forecasting process discusses how to get forecast results. Business analysis of the application process describes how forecasting is performed on the application. While the model representation illustrates the example of the calculation stages in forecasting.

\section{- Data requirements}

The data used in this study came from sales data of a company engaged in the export of palm shells. The location of the company is in South Jakarta which has a palm shell supply site in Sumatra and Kalimantan. Data collection is done through unstructured interviews with the company to obtain data on the functional requirements of the application, such as the features needed. Whereas the monthly sales data collection of the company is carried out with secondary document studies provided by the company in the form of sales journals. Sales data used are company sales data for three years, starting from January 2016 to December 2018. The data of the first two years, namely data from January 2016 to December 2017 are used as training data, while data from January 2018 to December 2018 data used as test data.

\section{- Functional requirements}

The following is an explanation of the features implemented in the application of palm shell sales forecasting.

a) "Login" and "Logout" features used to differentiate access rights for users.

b) "Home" feature that displays user information.

c) "Input Sales Data" feature in the form consisting of months, years, and number of sales to store monthly sales data into the database.

d) "View Sales Data" feature that displays monthly sales data that has been stored in the database. 
e) "Forecast Sales" feature used for forecasting, displays forecasting results where calculations are based on monthly sales data that has been saved and based on entering the period the user wants to predict. The forecasting results are automatically stored in the database.

f) "Review the Forecasting Result" feature that is used to display forecasting results that have been done before in the form of tables containing forecasting periods, forecasting results, and actual sales data if the data has been entered. The feature also provides a display of forecast results in the form of line graphs.

g) "Manage User" feature where user accounts can be added, edited, and deleted.

There are three actors involved in managing and using this application, namely Director of the Company, Manager of the Company, and Administration Section of the Company. The Director only has special permission to access functions related to forecasting, Managers have access rights to all the features available on the application including functions to manage users, and the Administration Section of the Company can only input sales data.

\section{- Forecasting process analysis}

The forecasting method used in making the forecasting application for the sale of palm shells is the Least Square method. The data used in this application is the company's monthly sales data for 2 years, starting from January 2016 to December 2017. The data is used for the calculation of forecasting the sale of palm shells in January 2018 until December 2018. Figure 2 is an illustration of the forecasting process using the Least Square method.

The process begins by entering sales data from January 2016 to December 2017 into the database. Then, users enter the sales period that they want to predict, for example, to do forecasting for the period January 2018 to December 2018. After that, forecasting calculations are carried out using the Least Square method based on the data that has been entered and produce the results of forecasting the sale of palm shells on the period of January 2018 to December 2018.

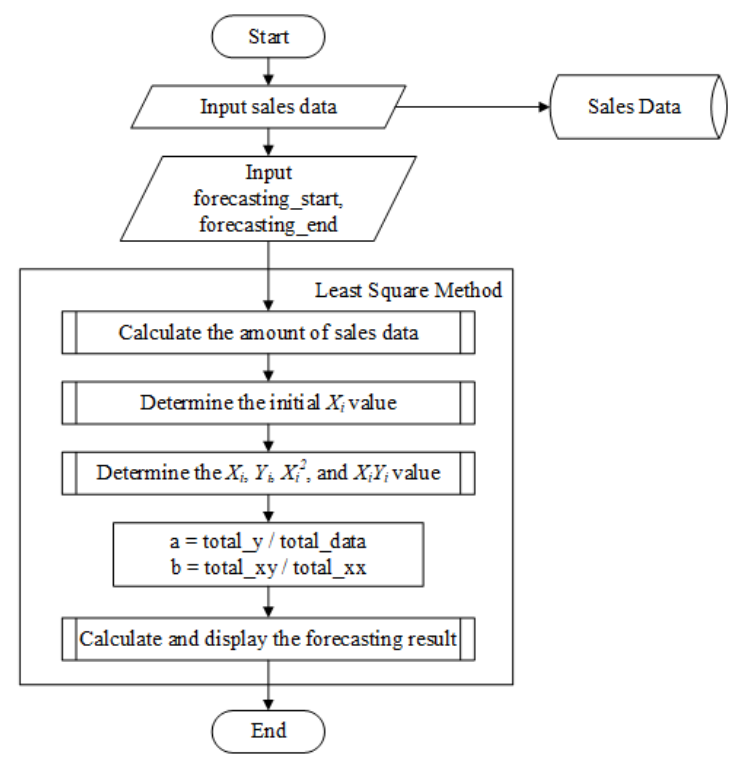

Fig. 2. Forecasting Process with Least Square Method

The calculation process using the Least Square method starts with calculating the amount of data that has been stored in the database through the process flow as shown in Figure 3. After the amount of data is obtained, the next step is determining the initial $\mathrm{Xi}$ value with the process flow shown in Figure 4.

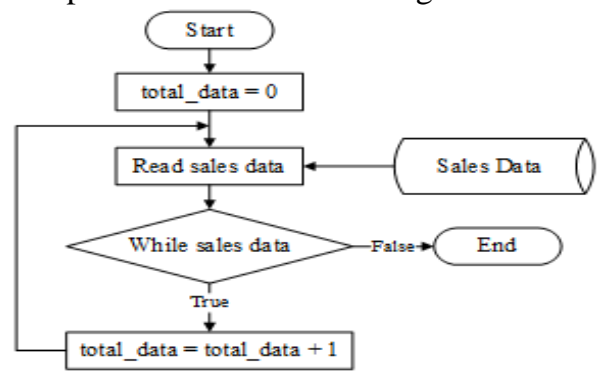

Fig. 3. Flowchart Sub-Process of Calculate the Amount of Data 


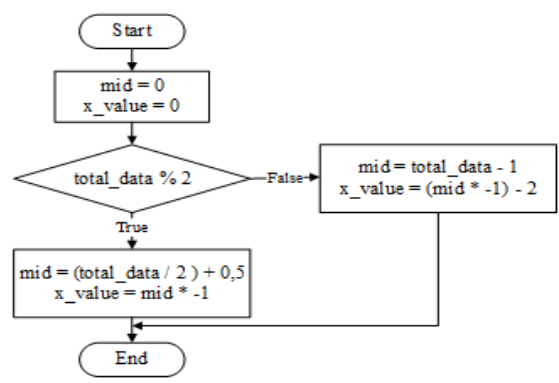

Fig. 4. Flowchart Sub-Process of Determine the Initial Xi Value

The next stage is determining the values of $\mathrm{Xi}, \mathrm{Yi}, \mathrm{Xi}$, $\mathrm{XiYi}$, and calculating the number of each variable with the process flow shown in Figure 5 that will be used to calculate values a and $\mathrm{b}$ in the equation in the Least Square method. Determination of the $\mathrm{Xi}$ value uses the midpoint value method as the initial $\mathrm{Xi}$ so sigma $\mathrm{Xi}$ must be equal to $0\left(\sum \mathrm{Xi}=0\right)$. In addition, determining the value of $\mathrm{Xi}$ also depends on the amount of data used in forecasting, whether it is odd or even.

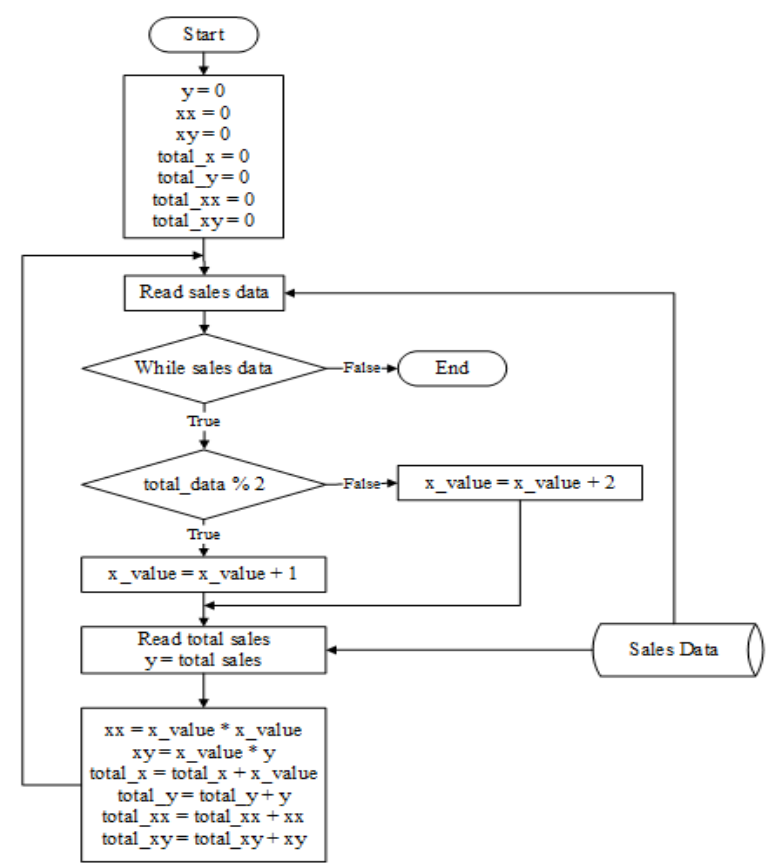

Fig. 5. Flowchart Sub-Process of Determine the Xi, Yi, Xi2, XiYi Values

After the values of $a$ and $b$ are known, an equation in the Least Square method is formed to calculate the forecast in the period entered with the process flow shown in Figure 6.

The $\mathrm{X}$ value in the Least Square equation is the $\mathrm{X}$ value in the selected forecasting period so it must be determined first, then sales forecast for the selected period is calculated. Forecasting results are saved to the database and displayed according to the forecast period chosen as the output.

\section{System Design}

The purpose of system design is to design a new system that can solve the problems faced by the company obtained from the best alternative selection system [10].

Use cases are a tool to communicate with users and other stakeholders about what the system wants to do [10]. It makes easy to know what the system will do and who will interact with it [11]. Use Case Diagram for the palm shell sales forecasting application is shown in Figure 8 where there are three actors, namely the Administration, Managers, and Directors. All actors must log in before entering the application. 


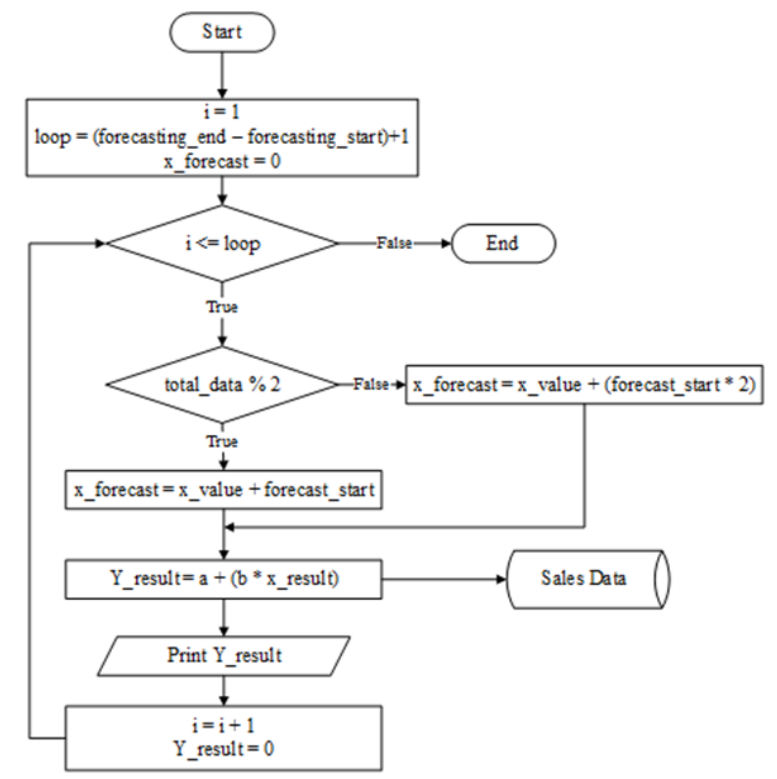

Fig. 6. Flowchart Sub-Process of Calculate and Display the Forecasting Result

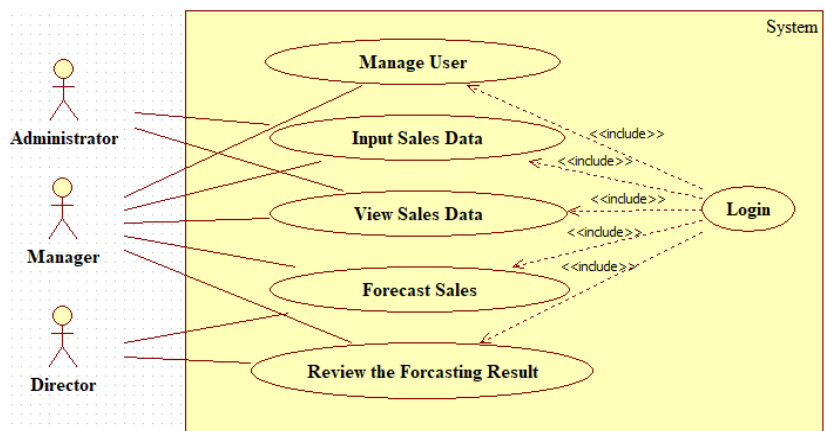

Fig. 7. Use Case Diagram for the Palm Shell Sales Forecasting Application

After logging in, the Administration can enter sales data, and view sales data that has been stored in the database. The director can forecast and look back at the forecast results that have been done before in the application. Managers can enter sales data, view sales data that has been stored in the database, do forecasting and look back at the forecast results that have been done before in the application, and also can manage users.

The database design used to store sales of palm shells, the results of forecasting the sale of palm shells, user data, and access rights are shown in Figure 9. There are four table namely: user, role, sales_data, and forecasting_result.

\begin{tabular}{|c|c|}
\hline user & \\
\hline \multirow{3}{*}{$\begin{array}{l}\text { +id_user } \\
\text { +id_role } \\
\text { +username } \\
\text { +password } \\
\text { tname }\end{array}$} & role \\
\hline & $\begin{array}{l}\text { Hid_role } \\
\text { +role_name }\end{array}$ \\
\hline & \multirow{2}{*}{$\begin{array}{l}\text { +create_user0 } \\
\text { +edit_user0 } \\
\text { +delete_user0 } \\
\text { +view_user0 }\end{array}$} \\
\hline $\begin{array}{l}\text { +create_user0 } \\
\text { +edit_user0 } \\
\text { +delete_user0 } \\
\text { +view_user0 }\end{array}$ & \\
\hline sales_data & \\
\hline \multirow{2}{*}{$\begin{array}{l}\text { +id_sales } \\
\text { +sales_period } \\
\text { +total_sales }\end{array}$} & forecasting_result \\
\hline & \multirow{2}{*}{$\begin{array}{l}\text { +id_forecast } \\
\text { +history_date } \\
\text { +forecast_period } \\
\text { tresult }\end{array}$} \\
\hline \multirow{2}{*}{$\begin{array}{l}\text { +save_sales0 } \\
\text { +edit_sales } 0 \\
\text { +delete_sales } 0 \\
\text { +view_sales } 0 \\
\text { +forecasting_sales } 0\end{array}$} & \\
\hline & $\begin{array}{l}\text { +forecasting_sales } 0 \\
\text { +review_result } 0\end{array}$ \\
\hline
\end{tabular}

Fig. 8. Class Diagram for the Palm Shell Sales Forecasting Application 


\section{Result}

Forecasting the sale of palm shells using actual sales data owned by the company, namely January 2016 to December 2017 that used in calculations using the Least Square method to make sales forecasts for the next period that want to predict. While the actual data on the sale of palm shells in January 2018 to December 2018 are used as test data. For example, making forecast sales of palm shells for the period of January 2018. The following are the steps that must be taken:

1) Calculate the amount of data used ( $\left.\sum \mathrm{n}\right)$, which is 24 data (sales data from January 2016 to December 2017).

2) Determine the value of the $\mathrm{Xi}$ parameters. The data used amounts to 24 and runs out if divided by two so that the data is even data, then the scale used is $\mathrm{Xi}=1 / 2$ year. The base period is placed between December 2016 and January 2017.

3) Yi parameters are the company's sales data, namely sales data from January 2016 to December 2017.

4) Determine the value of $\mathrm{Xi} 2$ and $\mathrm{XiYi}$. This step is useful to find out the values of $\mathrm{a}$ and $\mathrm{b}$ used in the equation in the Least Square method.

5) Sum all the values of $\mathrm{Xi}$ and the result must be $\sum \mathrm{Xi}=0$.

6) Sum all the values of $\mathrm{Yi}, \mathrm{Xi} 2$ and $\mathrm{XiYi}$, can be seen in Table 3.

Table 1. Calculation of Least Square

\begin{tabular}{|c|c|c|c|c|c|}
\hline Year & Month & $\mathrm{Xi}$ & $\mathrm{Yi}$ & $\mathrm{Xi}^{2}$ & $\mathrm{XiYi}$ \\
\hline 2017 & January & -23 & 41.891 & 529 & -963.493 \\
\hline 2017 & February & -21 & 47.779 & 441 & -1003.359 \\
\hline 2017 & March & -19 & 48.483 & 361 & -921.177 \\
\hline 2017 & April & -17 & 43.181 & 289 & -734.077 \\
\hline 2017 & May & -15 & 43.469 & 225 & -652.035 \\
\hline 2017 & June & -13 & 49.491 & 169 & -643.383 \\
\hline 2017 & July & -11 & 42.694 & 121 & -469.634 \\
\hline 2017 & August & -9 & 49.740 & 81 & -447.660 \\
\hline 2017 & September & -7 & 46.628 & 49 & -326.396 \\
\hline 2017 & October & -5 & 50.985 & 25 & -254.925 \\
\hline 2017 & November & -3 & 40.489 & 9 & -121.467 \\
\hline 2017 & December & -1 & 45.857 & 1 & -45.857 \\
\hline 2018 & January & 1 & 46.590 & 1 & 46.590 \\
\hline 2018 & February & 3 & 47.522 & 9 & 142.566 \\
\hline 2018 & March & 5 & 48.375 & 25 & 241.875 \\
\hline 2018 & April & 7 & 42.734 & 49 & 299.138 \\
\hline 2018 & May & 9 & 41.091 & 81 & 369.819 \\
\hline 2018 & June & 11 & 38.480 & 121 & 423.280 \\
\hline 2018 & July & 13 & 43.317 & 169 & 563.121 \\
\hline 2018 & August & 15 & 43.195 & 225 & 647.925 \\
\hline 2018 & September & 17 & 47.872 & 289 & 813.824 \\
\hline 2018 & October & 19 & 42.324 & 361 & 804.156 \\
\hline 2018 & November & 21 & 36.789 & 441 & 772.569 \\
\hline 2018 & December & 23 & 42.186 & 529 & 970.278 \\
\hline$\sum \mathrm{n}=$ & & $\sum \mathrm{Xi}$ & $\sum \mathrm{Yi}=$ & $\sum \mathrm{Xi} 2$ & $\sum \mathrm{XiYi}=$ \\
\hline 24 & & $=0$ & 1071.162 & 4600 & -488.322 \\
\hline
\end{tabular}


7) Calculate the value of a (the value of $\mathrm{Yi}$ if the value of $\mathrm{Xi}=0$ ) as in (1) and $\mathrm{b}$ (change of Yi variable for each change in $\mathrm{Xi}$ value) as in (2) based on the results of calculations that have been done.

$$
\begin{aligned}
& a=\frac{1071.162}{24}=44.632 \\
& b=\frac{-488.322}{4600}=-0.106
\end{aligned}
$$

8) The Least Square equation is obtained as in (3).

$$
Y=44.632+(-0.106) X
$$

9) The results of forecasting the sale of palm shells for January 2018 as in (4):

$$
Y=44.632+(-0.106)(25)=41.978 \text {. }
$$

10) Based on the results of sales forecasting using the Least Square method, sales for the period of January 2018 are estimated to be 41,978 tons of palm shells.

Forecasting is also calculated for February 2018 - December 2018 using the least square equation. Comparison chart of forecasting results with actual sales data shown in Figure 7 below.

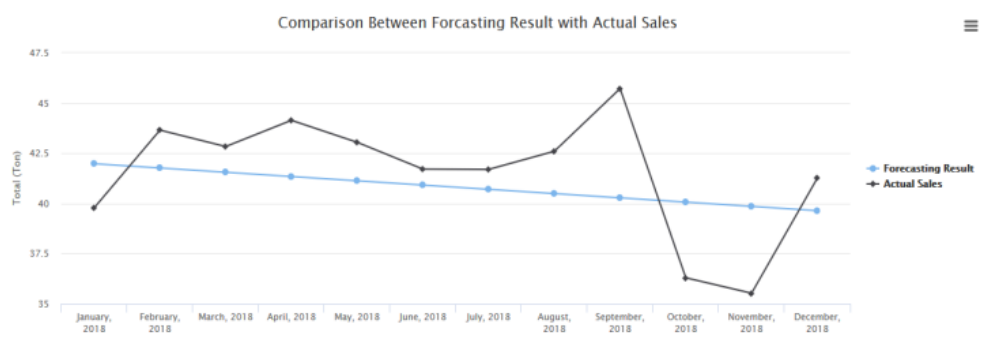

Fig. 9. Comparison Chart for Forecast Results with Actual Sales Data

The next step is calculating Mean Absolute Percentage Error (MAPE) for accuracy testing of the Least Square method in forecasting. MAPE states the percentage of error forecasting results for actual requests during a certain period that will give error percentage information whether too high or too low [8]. Forecasting ability is very good if it has a MAPE value of less than $10 \%$ and has good forecasting ability if the MAPE value is less than 20\% [9].

The data tested is the data on sales of palm shells in January 2018 to December 2018. The forecasting results

\begin{tabular}{|c|c|c|c|c|}
\hline Year & Month & $\mathrm{Xi}$ & $\hat{x} \mathrm{i}$ & $|\mathrm{RE}|$ \\
\hline 2018 & January & 39.785 & 41.978 & 0.055 \\
\hline 2018 & February & 43.653 & 41.766 & 0.043 \\
\hline 2018 & March & 42.834 & 41.553 & 0.030 \\
\hline 2018 & April & 44.140 & 41.341 & 0.063 \\
\hline 2018 & May & 43.046 & 41.129 & 0.045 \\
\hline 2018 & June & 41.712 & 40.916 & 0.019 \\
\hline 2018 & July & 41.695 & 40.704 & 0.024 \\
\hline 2018 & August & 42.600 & 40.492 & 0.049 \\
\hline 2018 & September & 45.720 & 40.279 & 0.119 \\
\hline 2018 & October & 36.299 & 40.067 & 0.104 \\
\hline 2018 & November & 35.531 & 39.855 & 0.122 \\
\hline 2018 & December & 41.257 & 39.642 & 0.039 \\
\hline \multicolumn{4}{|c|}{$\sum|\mathbf{R E}|$} & 0.712 \\
\hline
\end{tabular}
produced by the application are compared with the actual sales data of the company. The results of calculating the absolute value of relative error $(|\mathrm{RE}|)$ in each period can be seen in Table 4.

Table 2. Absolute Relative Error $(|\operatorname{RE}|)$ in each Period

The MAPE value can be calculated using the equation as in (5):

$$
M A P E=\left(\frac{0.712}{12}\right) 100 \%=5,935 \%
$$


The results of the MAPE calculation for the period January 2018 - December 2018 are 5,935\% where MAPE < 10\% means this method has a very good forecasting ability that continues to the design stage.

\section{A. Database and Program Implementation}

The database is implemented using MySQL and using localhost/phpmyadmin namely forecasting_sales, consisting of four tables, namely forecast_result, role, sales_data, and user, which is shown in Figure 10 below.

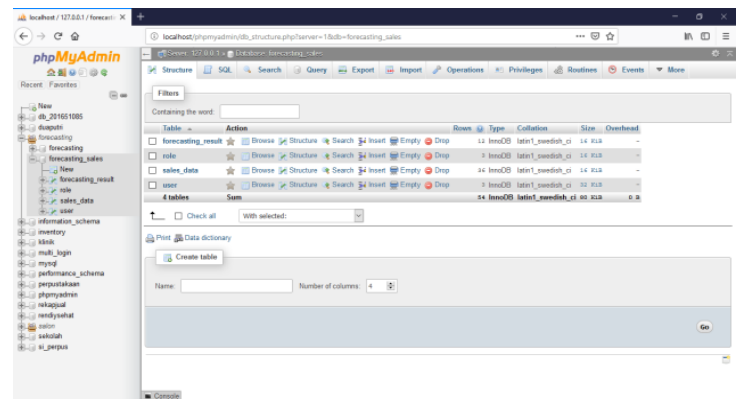

Fig. 10. Database Implementation

Program implementation is done by coding using PHP, HTML, CSS, Bootstrap, and JQuery. The first page of the application is the login page shown in Figure 11. After the user successfully log in, the home page will appear as shown in Figure 12.

Fig. 11. Login Page
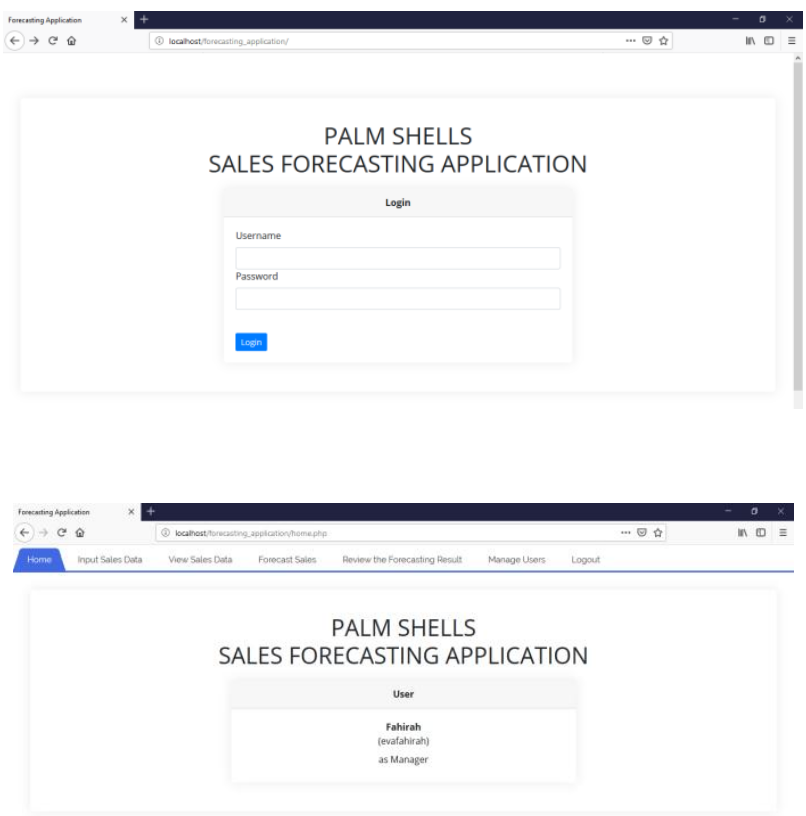

Fig. 12. Home Page

The forecasting process consists of several stages, first step is input sales data on the input sales data page shown in Figure 13 which can accessed by users with roles as Administration Sections and Manager. Sales data that has been entered is displayed in the form of a table on the page of view sales data shown in Figure 14. It can be accessed by the user with the role as the Administration Section and Manager. 


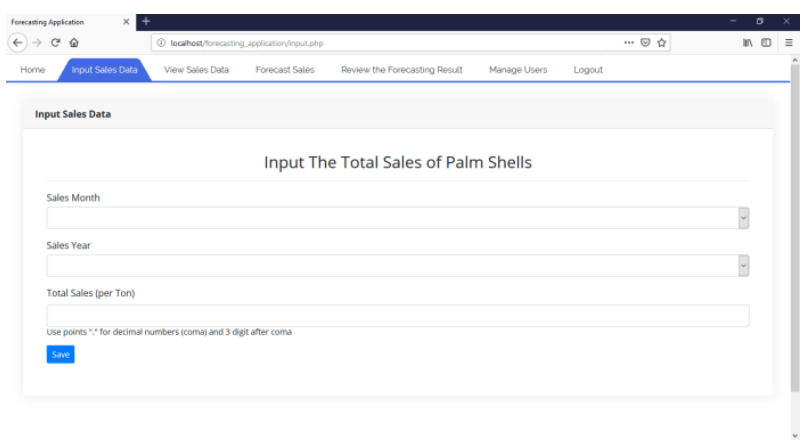

Fig. 13. Page of Input Sales Data

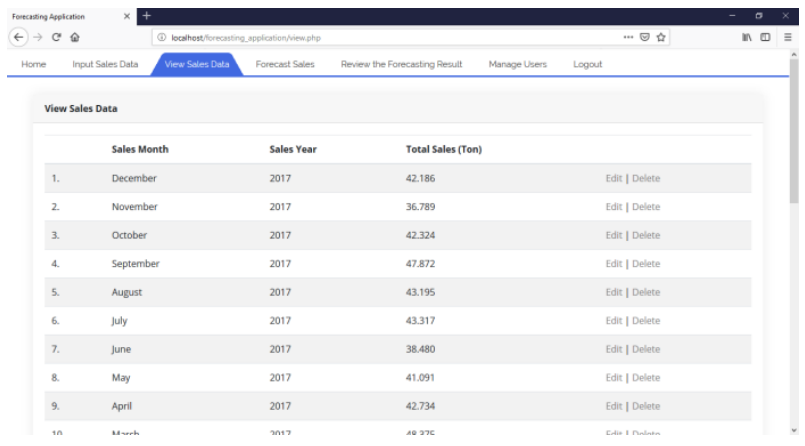

Fig. 14. Page of View Sales Data

Forecasting can be done on the forecast sales page shown in Figure 15 that can be accessed by users with roles as Manager or Director. To make a forecast, the user must select the range of forecasting period in the selection option then press the "Forecast" button. The forecasting results are also displayed on this page in a table shown in Figure 16 and will be automatically stored in the database.

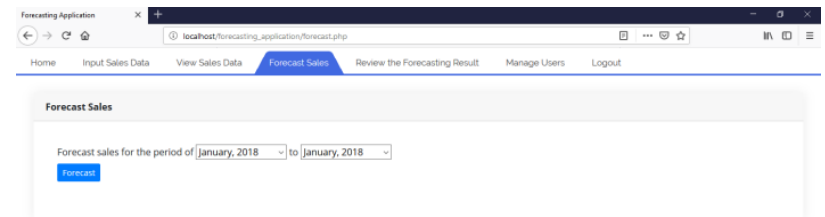

Fig. 15. Page of Forecast Sales

Fig. 16. Display of Forecast Results

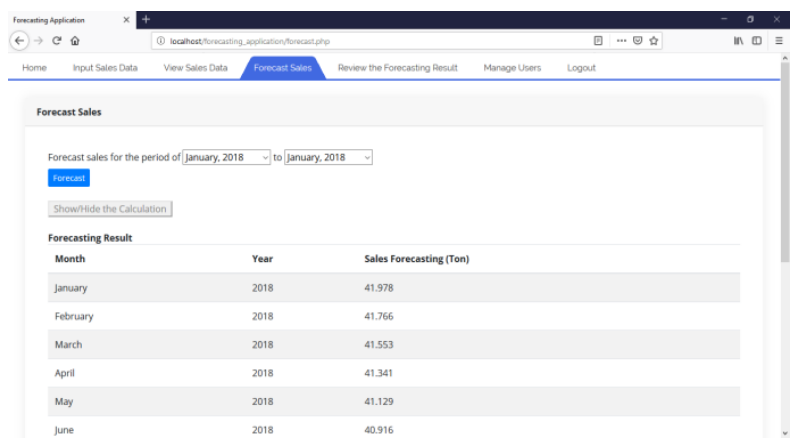

The forecasting results that have been carried out can be reviewed on the page of Review the Forecasting Result shown in Figure 17 that can be accessed by users with roles as Director and Manager. The table on that page provides information about the results of the forecasting that has been done and the actual sales data that has been entered into the database. 


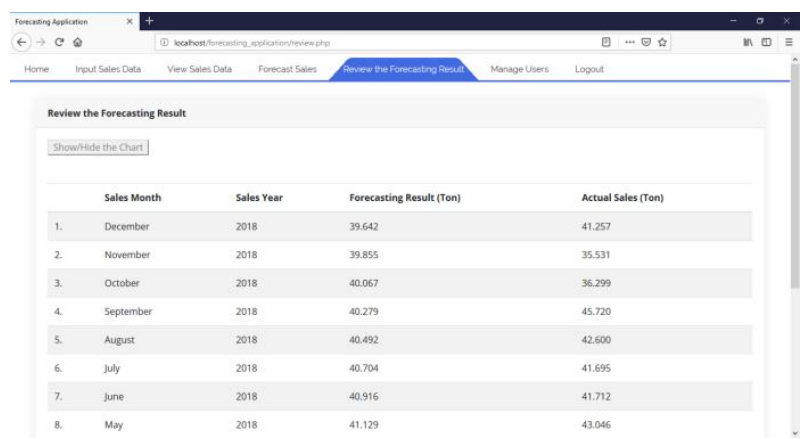

Fig. 17. Page of Review the Forecasting Result 18.

Users with roles as Manager can add, update, and delete other users on the page of Manage User, shown in Figure

Fig. 18. Page of Manage User

\section{B. Black Box Testing}

Black Box Testing is used to determine whether all software functions are running correctly in accordance with functional requirements that have been designed. Black box testing is also called behavior testing where the purpose is to verify the correctness of software behavior that directly supports daily business activities [12]. This test is carried out by the developer by providing certain inputs and seeing the output obtained. The result of Black Box Testing with 19 test cases showed that all test results were declared $100 \%$ successful. This means that the function of the software runs correctly according to the functional requirements that have been designed.

\section{User Acceptance Test}

The User Acceptance Test is carried out to test the output according to the user's needs. This test involves users to directly use the "Palm Shell Sales Forecasting Application" and provide an assessment of the application through a questionnaire about user satisfaction. Testing is done by taking a sample of two people, the Manager of the company and the Administration Section of the company.

From the calculations that have been done, the results of the assessment are 4 from 5 . That means the user agrees that the application can be operated easily and effective. The user interface design is quite good, consistent, and responsive. The menus contained in the application are easy to understand and according to needs. Data input process, sales forecasting, and user management can be done easily, effective, and run well. The choice of forecasting period on the form is in accordance with the requirements. Sales data and forecast result are clearly displayed, and the sales forecasting application can help the company to estimate sales for the next period.

\section{Conclusion}

Based on this study, it can be concluded that the research objectives have been achieved. The least square method for forecasting has been successfully implemented with an error percentage of $5.935 \%$ which is calculated using Mean Absolute Percentage Error (MAPE). It also can be seen that the Palm Shell Sales Forecasting Application successfully implemented the Least Square method to determine the sales target of palm shells for the next period which is more accurate and more objective based on calculations from past data. Table 5 is the result of forecasting the sale of palm shells for the period January 2018 to December 2018. 
Table 3. Forecasting Result

\begin{tabular}{|c|c|c|c|c|}
\hline Year & Month & $\mathrm{Xi}$ & $\hat{\mathrm{x} i}$ & $|\mathrm{RE}|$ \\
\hline 2018 & January & 39.785 & 41.978 & 0.055 \\
\hline 2018 & February & 43.653 & 41.766 & 0.043 \\
\hline 2018 & March & 42.834 & 41.553 & 0.030 \\
\hline 2018 & April & 44.140 & 41.341 & 0.063 \\
\hline 2018 & May & 43.046 & 41.129 & 0.045 \\
\hline 2018 & June & 41.712 & 40.916 & 0.019 \\
\hline 2018 & July & 41.695 & 40.704 & 0.024 \\
\hline 2018 & August & 42.600 & 40.492 & 0.049 \\
\hline 2018 & September & 45.720 & 40.279 & 0.119 \\
\hline 2018 & October & 36.299 & 40.067 & 0.104 \\
\hline 2018 & November & 35.531 & 39.855 & 0.122 \\
\hline 2018 & December & 41.257 & 39.642 & 0.039 \\
\hline \multicolumn{5}{|c|}{$\sum|\mathbf{R E}|$} \\
\end{tabular}

Forecasting results generated by the application form a trend pattern that illustrates the palm shell sales have a tendency to either increase or decrease over time as shown in Figure 19. In other words, the amount of palm shell sales will increase or decrease over a long period. This can be used by companies to see how the development of palm shells sales in the coming periods.

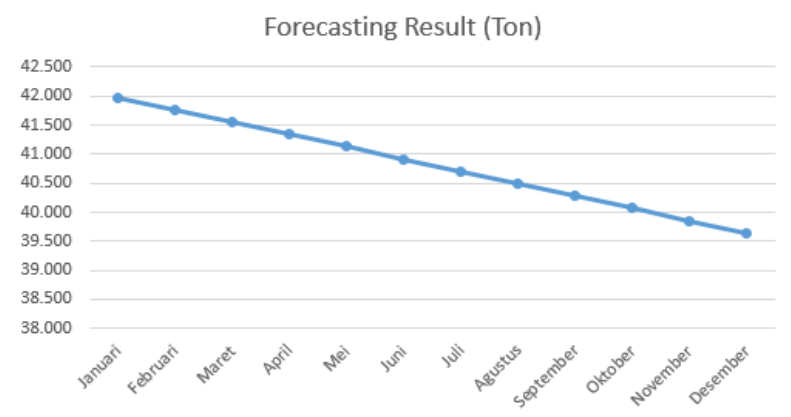

Fig. 19. Chart of Forecasting Results

In addition, the company can also use the results of this forecast to determine the sales target of palm shells in the next period to manage the supply of palm shells at the inventory. The management of palm shell stock by using the results of this forecast is useful for knowing the estimated amount of palm shell stock that must be prepared at the inventory so that the available supply will be balanced with client demand.

Based on data testing using Mean Absolute Error (MAPE) shows that the error generated in forecasting using the Least Square method is $5.935 \%$ that means the success rate is $94.065 \%$. Based on black box testing shows that the test case results reach $100 \%$. While based on User Acceptance Testing shows users agree that the forecasting application for sales of palm shells in accordance with the requirements and forecasting results is clearly displayed so that it can help companies to estimate sales for the next period.

This application still needs to be developed to make it better and more useful for future work as: 1) using other tools that support designing and developing forecasting applications such as python and R programming, 2) comparing the Least Square method with other forecasting methods to find out the best method, for example the Single Exponential Smoothing method, the Autoregressive Integrated Moving Average (ARIMA) method, 3) add features that more complete and in accordance with the needs of the company, and can be integrated with other systems, and 4) this application of palm shell forecasting can be used for other problems by adjusting the type of data used in this research, namely numerical data.

\section{References}

[1] M. S. Brown, Data Mining for Dummies, Hoboken: John Wiley \& Sons, Inc., 2014.

[2] R. J. Roiger, Data Mining: a Tutorial-Based Primer, 2nd ed., Boca Raton: CRC Press, Taylor \& Francis Group, 2017.

[3] M. Ihsan, H. Rosyid, and E. Prasetyo, "Perancangan Aplikasi Peramalan Penjualan Motor Honda Menggunakan Metode Least Square (Studi Kasus: PT. HD Motor 99 Gresik)", unpublished.

[4] L. Stepvhanie, "Peramalan Penjualan Produk Susu Bayi dengan Metode Grey System Theory dan Neural Network," University of Indonesia, Depok, 2012.

[5] M. F. Alamsyah and R. Arnie, "Model Aplikasi Prediksi Penjualan Sepeda Motor dengan Metode Single Moving Average", JUSTISI, 4(2), 729-796, 2015. 
[6] D. P. Pamungkas, "Implementasi Metode Least Square untuk Prediksi Penjualan Tahu Pong”. NERO Scientific Journal, 2(2), 75-81, 2016.

[7] F. R. Hariri, "Metode Least Square Untuk Prediksi Penjualan Sari Kedelai Rosi," Junal SIMETRIS, vol. 7, no. 2, pp. 731-736, 2016.

[8] N. L. A. K. Yuniastari and I. W. W. Wirawan, "Peramalan Permintaan Produk Perak Menggunakan Metode Simple Moving Average Dan Exponential Smoothing," Jurnal Sistem dan Informatika, vol. 9, no. 1, pp. 97-106, 2014.

[9] A. E. Indriyana, "Aplikasi Peramalan Penjualan Tiket Pesawat Menggunakan Metode Trend Moment (Studi Kasus: Maskapai Penerbangan XYZ)," Gunadarma University, Jakarta, 2017.

[10] U. T. Hantoro, "The Implementation of Machine Learning Method for Tweets Classification in Indonesian Language," Gunadarma University, Jakarta, 2017.

[11] "Tutorial - Building a Use Case Diagram," University of Cyprus, Department of Computer Science, 26 February 2010. [Online]. Available: https://www.cs.ucy.ac.cy/ ep1233/labs/EPL233-Lab7.pdf. [Accessed 3 February 2019].

[12] G. D. Everett and R. McLeod, Software Testing - Testing Across the Entire Software Development Life Cycle, Hoboken: John Wiley \& Sons, Inc., 2007.

\section{Authors' Profiles}

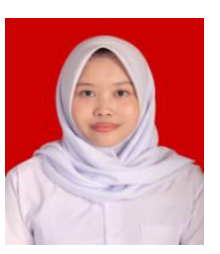

Fahirah was born in Jakarta, Indonesia on January $19^{\text {th }}$, 1998. In 2019, she received his Bachelor of Computer degree from the Information Systems Department, Faculty of Computer Science and Information Technology, Gunadarma University, Depok, Indonesia. She is currently undergoing a Masters program in Information Systems Management at Gunadarma University.

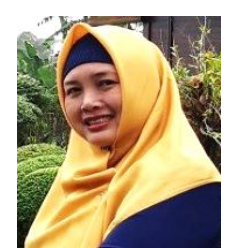

Lily Wulandari was born in Jakarta, Indonesia on March $6^{\text {th }}, 1969$. She completed her doctorate in Information Technology at the Gunadarma University in Depok, Indonesia in 2009. A Master's Degree in Information Systems was obtained from Gunadarma University, Depok, Indonesia in 1998. Undergraduate education in the field of Informatics Management obtained in 1994 from Gunadarma University, Depok, Indonesia. She is a lecturer at the Faculty of Computer Science and information technology at Gunadarma University, Depok, Indonesia. The research that is of interest is data mining and Natural Language Processing.

How to cite this paper: Fahirah, Lily Wulandari, " The Implementation of Least Square Method on the Palm Shells Sales Forecasting Application", International Journal of Information Engineering and Electronic Business(IJIEEB), Vol.12, No.5, pp. 1-13, 2020. DOI: 10.5815/ijieeb.2020.05.01 